\title{
P01.53. Spheroid formation and axonal severing in adult neurons during oxidative stress: role of calcium
}

\author{
A Barsukova-Bell $^{1 *}$, M Forte $^{2}, \mathrm{D}$ Bourdette ${ }^{3}$ \\ From International Research Congress on Integrative Medicine and Health 2012 \\ Portland, Oregon, USA. 15-18 May 2012
}

\section{Purpose}

Axonal severing is critical to the irreversible disability that occurs over the course of multiple sclerosis (MS). Reactive oxygen species (ROS) are implicated in neurodegenerative aspects of MS: axonal spheroid formation, severing, and axoplasmic $\mathrm{Ca}^{2+}$ elevation. However, the exact role of $\mathrm{Ca}^{2+}$ in spheroid formation remains unclear. The mechanism of action of natural anti-oxidants such as lipoic acid, which provide neuroprotection during oxidative stress in MS model, also remains unclear.

\section{Methods}

Primary cortical neurons from adult mice were subjected to physiologically-relevant levels of $\mathrm{H}_{2} \mathrm{O}_{2} \cdot \mathrm{Ca}^{2+}$ dynamics and its sources were examined during spheroids formation using real time imaging, ratiometric $\mathrm{Ca}^{2+}$ indicators and immunocytochemistry.

\section{Results}

Exposure to ROS led to a 3.5 fold increase in axoplasmic $\mathrm{Ca}^{2+}$ by $30 \mathrm{~min}$. Onset of axonal spheroid formation began at 15 min when $\mathrm{Ca}^{2+}$ increase was 2.2 fold. Axonal severing occurred at sites of spheroids around 90-120 min. Analysis of small axonal segments revealed an uneven distribution of $\mathrm{Ca}^{2+}$ during exposure to $\mathrm{H}_{2} \mathrm{O}_{2}$. Micrometers apart, focal $\mathrm{Ca}^{2+}$ increases in small axonal domains ranged from 2.8 to 4.4 fold. Domains with a 3.8 to 4.4 -fold increase correlated with the sites of spheroids, suggesting high focal extracellular $\mathrm{Ca}^{2+}$ influx at these sites. Several treatments significantly attenuated $\mathrm{Ca}^{2+}$ increase and completely abolished spheroid formation under ROS: removal of extracellular $\mathrm{Ca}^{2+}$;

${ }^{1}$ Oregon Health \& Science University, Department of Neurology, Portland, USA

Full list of author information is available at the end of the article
N-type $\mathrm{Ca}^{2+}$ channel blocker omega-conotoxin GVIA; L-type $\mathrm{Ca}^{2+}$ channel blocker amlodipine; and reverse $\mathrm{Na}+$ / $\mathrm{Ca}^{2+}$ exchanger (NCX1) blocker KB-R7943. Aggregation of reverse NCX1 and N-type voltage-gated $\mathrm{Ca}^{2+}$ channel was detected at spheroids.

\section{Conclusion}

Our results reveal a correlation between focal axoplasmic $\mathrm{Ca}^{2+}$ and spheroid formation and suggest that focal aggregation of the reverse NCX1 and N-type $\mathrm{Ca}^{2+}$ channel plays central role in high focal $\mathrm{Ca}^{2+}$ increase during oxidative stress. These findings provide a basis for investigating the neuroprotective mechanism of the natural anti-oxidant lipoic acid during oxidative stress.

\section{Author details \\ 'Oregon Health \& Science University, Department of Neurology, Portland, USA. ${ }^{2}$ Vollum Institute, Oregon Health \& Science University, Portland, USA ${ }^{3}$ Department of Neurology, Oregon Health \& Science University, Portland, USA.}

Published: 12 June 2012

doi:10.1186/1472-6882-12-S1-P53

Cite this article as: Barsukova-Bell et al:: P01.53. Spheroid formation and axonal severing in adult neurons during oxidative stress: role of calcium. BMC Complementary and Alternative Medicine 2012 12(Suppl 1): P53.
() Biomed Central

(c) 2012 Barsukova-Bell et al; licensee BioMed Central Ltd. This is an Open Access article distributed under the terms of the Creative Commons Attribution License (http://creativecommons.org/licenses/by/2.0), which permits unrestricted use, distribution, and reproduction in any medium, provided the original work is properly cited. 